\title{
The Effect of Using Communicative Language Teaching Activities on EFL Students' Speaking Skills at the University of Jeddah
}

\author{
Shorouq Ali AL-Garni ${ }^{1} \&$ Anas Hamed Almuhammadi ${ }^{1}$ \\ ${ }^{1}$ English Language Institute, King AbdulAziz University, Jeddah, Saudi Arabia \\ Correspondence: Shorouq Ali AL-Garni, English Language Institute, Jeddah University, Jeddah, Saudi Arabia.
}

Received: April 16, 2019 Accepted: May 8, 2019 Online Published: May 10, 2019

doi: 10.5539/elt.v12n6p72 URL: https://doi.org/10.5539/elt.v12n6p72

\begin{abstract}
The aim of the present study was to examine the effect of using communicative language teaching (CLT) activities on EFL students' speaking skills at the English Language Institute (ELI) of the University of Jeddah (UJ). The researcher conducted the current study in two classes of 21 female EFL students each; one class was the experimental group and the other the control group. The experimental group was taught using three communicative activities - interviewing, problem-solving, and role-playing — while the control group was taught using traditional methods. The current study followed a quasi-experimental study to answer the primary research question. The quasi-experimental study was conducted using a pre- and post-test design to determine if there was a significant difference between the scores of the experimental and control groups. The findings of the current study show that the experimental group scored higher than the control group. These findings have positive implications for the continued implementation of CLT teaching practices at the ELI of UJ.
\end{abstract}

Keywords: communicative language teaching, CLT activities, interviewing, problem-solving, role-playing, speaking skills, EFL

\section{Introduction}

\subsection{CLT in the Saudi Context}

English is a mandatory subject that must be taught in any educational curriculum at the university level in Saudi Arabia. Although activity-based curricula are implemented in universities for students to practice oral communication inside and outside the classroom, many researchers have concluded that students need more practice to better their performance (Al-Seghayer, 2011; Farooq, 2012). Derakhshan et al. (2015) noted that speaking-skills pedagogy has been developing over the past four decades in second language teaching and learning. Such skills require constant practice through group activities (Celce-Murcia, 2001). Therefore, communicative language teaching (CLT) is perhaps the most commonly used approach used to help students communicate effectively with each other (Larsen-Freeman, 2000).

CLT can best be implemented in the Saudi context through using appropriate activities in the classroom to improve EFL learners' speaking skills. CLT can be effective in dealing with Saudi students' deficiencies in spoken communication in English. Therefore, the present research has been conducted to highlight the effectiveness of the CLT approach in an EFL classroom in a Saudi university. The following section outlines the purpose of carrying out this research.

\subsection{Statement of the Problem}

A gap in the literature was identified regarding CLT adoption in the classroom; specifically, there is a paucity of studies on implementing CLT in EFL classrooms in Saudi Arabia. However, some studies have tried to shed light on the issue, such as by investigating the challenges and difficulties that teachers face when implementing CLT activities in the classroom (Al Asmari, 2015; Siddiqui \& Asif, 2018). Moreover, a study in the Saudi context investigated EFL learners' opinions about the use of communicative and non-communicative activities for learning English and determined the types of activities that increase students' anxiety (Algonhaim, 2014). Furthermore, many studies have concluded that the implementation of CLT activities in EFL classrooms is challenging (Karavas-Doukas, 1996; Li, 1998; Hiep, 2007). Therefore, the current study will examine the effect of using CLT activities on EFL students' speaking skills at the ELI of the University of Jeddah (UJ). The research question addressed by the current study is presented in the next section. 


\subsubsection{Research Question}

Is there any difference between the experimental and control groups in terms of the enhancement of their speaking skills at the ELI of UJ?

\subsection{Literature Review}

\subsubsection{Speaking Skills}

Speaking is defined as "the process of building and sharing meaning through the use of verbal and non-verbal symbols, in a variety of contexts" (Chaney \& Burk, 1998, p. 13), and it is regarded as an essential skill in learning and teaching English as a foreign language (EFL). Over the years, speaking has been undervalued and its importance unrecognized; a lot of teachers used to teach it through repetition practice and memorizing dialogues (Kayi, 2012). However, it has more recently been acknowledged that the aim of teaching speaking skills is to enhance students' communication skills to enable them to express themselves freely and communicate effectively with others (Kayi, 2012).

\subsubsection{Enhancing Students' Speaking Ability}

The integration of productive skills (e.g., writing and speaking) is very important for the enhancement of practical communication ability (Boonkit, 2010). One ability that is required for communication is speaking (Zaremba, 2006). Interaction through speaking is useful and creates many benefits for learners and business establishments. For instance, efficient speaking leads to accomplishments through speaking activities during ceremonies, job interviews, and activities for job training (Osborn et al., 2008). Zaremba (2006) indicated that speaking and communication skills are prioritized over work experience, motivation, and academic accreditation in new employment standards. EFL students not only have a limited opportunity to speak English outside the classroom (Zhang, 2009) but also have little opportunity to communicate with English speakers (Boonkit, 2010). To address this situation, teachers try to provide students with real-life situations and communicative activities to increase their speaking competency. Many factors need to be considered for bettering students' speaking performance (Boonkit, 2010). Such factors include pronunciation, vocabulary, and collocations to enhance students' speaking fluency. Moreover, students' level of confidence leads to better speaking performance (Boonkit, 2010). Patil (2008) confirmed that increasing students' self-confidence resulted in reduced fear of making errors, which will allow them to feel more comfortable with the use of the target language. In addition, Songsiri (2007) suggested that enhancing students' speaking ability is achieved through providing them with a variety of course activities and encouraging them to have more exposure to the target language through listening to the media. Students should be required to seek opportunities to speak English in real situations, which may result in promoting their speaking skills and self-confidence (Songsiri, 2007).

\subsubsection{The Background of CLT}

CLT is categorized as a broad approach to foreign language teaching rather than a teaching method with an apparent and defined record of classroom practices (Banciu \& Jireghie, 2012). As a movement, CLT grew apart from traditional methods of teaching that focus on grammar mastery through planned and structured activities that include memorizing dialogues, role plays, and project work (Richards, 2006). CLT is described as "activities where practice in using language within a real communicative context is the focus, where real information is exchanged, and where the language used is not totally predictable" (Richards, 2006, p. 16).

Richards and Rogers (2001) suggested that the CLT approach is beneficial since it focuses on the development of the four skills on which language and communication depend; this approach aims at fostering EFL learner's competence in communication. EFL learners can be communicatively competent in the target language if they work hard on developing their communicative competence, which is the ability to communicate effectively using the target language within social happenings (Hiep, 2007).

Hiep (2007) argued that CLT is based on the idea that learning the target language occurs when classroom practices are meaningful and genuine to the learners; Alwazir and Shukri (2016) added that these practices need to be about real-life situations that entail communication. The main goals of CLT are creating opportunities for learners to use the target language effectively for everyday communication needs; giving learners the ability to express their opinions explicitly without being afraid of judgement; and removing their fears to allow them to speak effectively in public (Hiep, 2007).

Teachers and learners have important roles which contribute to the success of CLT in the classroom. On the one hand, EFL learners play the role of negotiators with one another in cooperative rather than individualistic tasks. Instead of relying entirely on the teacher as the source of knowledge, learners feel more comfortable listening to their peers in pair or group tasks (Richards \& Rodgers, 2001). Learners can learn best through listening to their 
classmates making mistakes and correcting themselves. Therefore, in CLT, learners are encouraged to be more confident about following their peers' steps in improving their speaking skills.

On the other hand, teachers play the role of monitors and facilitators of the learning process instead of models of correct, error-free speech (Richards \& Rodgers, 2001). As a result, anxious learners are encouraged to start learning how to predict their own mistakes and correct them accordingly through relying on the teacher as a facilitator of the learning process in the classroom. The following section discusses CLT activities in the classroom.

\subsubsection{Difficulties in Implementing CLT in the EFL Classroom}

EFL learners encounter many obstacles that prevent them from improving their speaking skills in the Saudi context. First, students may lack opportunities that allow them to practice oral communication with each other (Wajid \& Saleem, 2017). One teacher suggested that she was unable to use CLT activities in the classroom because these activities help students acquire proficiency instead of practicing grammar and sentence structure (Richards \& Rodgers, 2001).

Second, students in Saudi universities are used to memorizing paragraphs and textbook exercises when they prepare for their tests. Such practices hinder the improvement of their speaking proficiency (Alwazir \& Shukri, 2016).

Third, some EFL students have had bad experiences when trying to learn the English language because of a lack of effective implementation of learning strategies and activities in the classroom. These bad experiences often lead them to form negative viewpoints about the possibility of learning the English language which take a lot of time to overcome (Alwazir \& Shukri, 2016). Many research studies have concluded that teaching and learning English in the Arab context was not successfully implemented (Rababah, 2003; Al-Jarf, 2008). Similarly, Al-Hazmi (2006) claimed that teaching English in the Arab context is based on "a traditional, top-down, textbook-oriented, teacher-led methodology" (p. 38).

Fourth, teachers face a tiring task in making Saudi learners practice English efficiently as those learners have limited exposure to and understanding of the target language. Saudi learners encounter difficulties in acquiring speaking and writing skills since they communicate in Arabic everywhere (Khan, 2013).

Fifth, Shumin (2002) found that Saudi learners of English hesitate to speak English due to their lack of exposure to real-life situations. Such situations would allow them to use the target language for communication and voicing their opinions.

In addition, Alwazir and Shukri (2016) asserted that students can improve vocabulary learning and grammar mastery through relying on memorization, although they may face other difficulties in acquiring the English language. Until recently, EFL students have been considered passive learners when it comes to acquiring the target language in the classroom. Moreover, their participation in the classroom has often been limited to one or two sentences as a response to their teacher's questions (Jamjoom, 2009). Owing to social and psychological reasons, students feel stressed and nervous to speak English in the classroom, which tends to make them opt for silence (Koran, 2015). To put it simply, EFL students are neglected in speaking sessions when they feel too shy or nervous to speak in front of their classmates. Moreover, teachers may not have enough time to motivate them to speak. Finally, traditional teaching methods create dull and anxious educational environments where students become demotivated; consequently, they lack any spirit of innovation or critical thinking (Alharbi, 2015).

\subsubsection{Usefulness of CLT}

CLT is affirmed to be the most used and well-known approach to help students communicate effectively (Larsen-Freeman, 2000). It is an approach with many distinctive characteristics. Richards and Rogers (2001) argued that one of these distinctive attributes is that the teaching process is learner-centred and experience-based. Moreover, Richards (2006) asserted that CLT has several unique features, such as making genuine communication the target of learning English as well as giving students opportunities to reflect upon their experiences and what they know (Richards, 2006). Through CLT, students enhance fluency and accuracy, use the four skills interchangeably since they exist together in the real world, and generate and discover grammatical rules. CLT deals with learning the English language as an ongoing process that focuses on learning from trial-and-error practices that result in facilitating the learning process (Richards, 2006). There are many advantages to involving students in pair and group work activities (Richards, 2006). One of the advantages is that students learn the target language through listening to other members in group activities. Students learn more vocabulary items and grammatical patterns and enjoy increased motivation levels in group or pair work activities rather than in a teacher-centred classroom (Richards, 2006). 
Brown (1993) pointed out that it is more important to learn to speak the target language fluently and to be understood by others than to learn grammar and sentence structure. Moreover, CLT is significant in highlighting the importance of not correcting students' oral mistakes while they are speaking since trial-and-error practice is a part of the development of their speaking ability. Therefore, it is better to keep students' errors in mind during the activity and then point them out after the activity finishes (Brown, 1993). Teachers need to implement CLT activities in the classroom to increase students' interest and class participation, thereby improving their performance (Uzoma \& Ibrahim, 2018); in contrast, teacher-centred classrooms need to become less common. In sum, more promotion of CLT implementation in the classroom is needed (Uzoma \& Ibrahim, 2018).

\subsubsection{CLT Activities in the EFL Classroom}

Communicative activities are important to stimulate students' communication with each other in the English class, and these activities should be ranged from easy to more complex based on the level of the students. Moreover, teachers should provide their students with constant scaffolding and feedback for each activity they are involved in (Banciu \& Jireghie, 2012). Oradee (2012) asserted that such communicative activities include information gaps, jigsaw activities, problem-solving, and role-playing, all of which can improve students' speaking skills. Hedge (2008) suggested that free discussion and role-playing are better for enhancing students' oral production. In light of the above, the following three paragraphs discuss the main communicative activities which will be used in the current study.

\subsubsection{Interview}

Communicative activities include interviews that play an important role in developing students' fluency. Students can choose topics that they are familiar with and then conduct interviews with various people. Conducting interviews gives students the opportunity to practice speaking with others and makes them more sociable (Kayi, 2012). The interview can be very successful if the interviewer is skilful enough to ask the right questions, insist on meaningful answers, interpret the interviewee's answers correctly, and engage in a meaningful and fruitful discussion with the interviewee. Both the interviewer and interviewee need to be good at listening so that the question-and-answer sequence advances into a meaningful conversation (Klippel, 1984). It can be a good idea if the teacher provides students with a rubric so that they understand the types of questions they can ask and the sequence they can follow in the interview. However, students need to prepare the interview questions on their own (Kayi, 2012).

\subsubsection{Problem-solving}

Another intriguing activity that can improve students' oral communication is problem-solving. Students can be given a problem or an issue and some information to help them fully understand the problem. Then, they are asked to find a suitable resolution to the problem (Richards \& Rodgers, 2001). The language needed for problem-solving activities depends on the type of topic for each exercise. In addition, students can be requested to make suggestions, provide reasons, and even accept or reject the suggestions and reasons provided by other classmates (Klippel, 1984). Students are thereby given the opportunity to use their critical thinking effectively in finding solutions for real-life problems.

\subsubsection{Role-Playing}

Role play is an effective communicative activity that can be used to enhance students' speaking ability through creating real-life situations in a conversation form (Huff, 2012). Tompkins (1998) identified role play as a teaching procedure that encourages students' participation in the learning process. Thus, students can overcome shyness and speaking anxiety through intensive practice in creating scenarios about real-life situations.

\subsubsection{Previous Studies of CLT}

$\mathrm{Wu}$ (2010) explored the relationship between students' language-learning strategies using CLT and their anxiety level in an EFL classroom. The findings showed that although implementing CLT in the classroom can be challenging to some extent, it is nonetheless considered a valid teaching method that should be applied.

Algonhaim (2014) investigated Saudi students' perceptions towards communicative and non-communicative activities in the classroom. The findings demonstrated that students were in favour of the implementation of both communicative and non-communicative activities' in the EFL classroom.

Al Asmari (2015) examined the difficulties and challenges that face teachers when implementing CLT in the classroom. The findings showed that teachers had difficulty accessing CLT materials and were unable to prepare CLT activities for their students due to the limited time of the classroom and a lack of CLT training. In addition, students' passive learning style, lack of motivation, low proficiency level, and resistance to participation in 
communicative activities were major challenges for the teachers. Therefore, teachers need more training on communicative activities and students need to become more autonomous to be able to improve their speaking ability.

Azadi et al. (2015) investigated the effect of classroom interaction in enhancing students' speaking ability. The research findings demonstrated that students' communication inside the classroom developed their speaking ability. The study researchers asserted that reinforcing classroom interaction will improve EFL students' speaking proficiency. Azadi et al. (2015) suggested that devoting some hours of classroom time for students to interact with each other and motivating them to have profound conversations would lead to a more communicative environment.

Ochoa et al. (2016) explored the relationship between CLT activities and their effect on students' motivation to learn the English language. The research results showed that EFL students considered CLT activities to be motivating. Moreover, students felt more motivated when they were involved in communicative activities because such activities helped them improve their fluency, pronunciation, and performance when using English for communication. They felt more confident when they interacted with each other in communicative activities such as class discussions, games, pair/group work, role plays, and oral presentations within groups. The researchers recommended that teachers use each communicative activity more than once to promote opportunities for students to practice English, encourage them to be independent learners, and create an effective, friendly atmosphere for them in the classroom. They also suggested that teachers need to give students continuous constructive feedback and error correction on their performance during these activities to motivate them even more. Last, they recommended that teachers provide equal opportunities for students to participate and interact in the classroom to achieve efficient results.

Wajid and Saleem (2017) investigated EFL learners' opinions to estimate the influence of their conformity attitude and its level on the implementation of communicative activities in the classroom. The findings of the study demonstrated that EFL learners at King Abdul-Aziz University (KAU) exhibited attitudes of conformity towards improving their speaking skills through communicative activities. Moreover, the learners showed a very high level of conformity regarding implementing CLT in the classroom. Therefore, this study can be considered evidence of the effectiveness of CLT for improving students' speaking ability.

\section{Methodology}

The current study followed a quasi-experimental method and the quantitative data were collected from pre- and post-tests. In the quantitative phase, a pre-test was conducted before the intervention for an experimental and control group. One intervention was conducted with the experimental group per weekly speaking season for three weeks. After the intervention, a post-test was given to both groups to demonstrate if there was any improvement.

\subsection{Participants}

The selection of participants is a convenience sampling because the participants were selected based on their availability at the time of the experiment, easy accessibility at the ELI of UJ, and their willingness to volunteer in the current study (Dörnyei, 2007). The current study is specific to Saudi female EFL students in the preparatory year at UJ. The participants were 21 students from two classrooms, and their age ranged from 18 to 25 . Both groups were chosen to be in Level 2 because the current study required the participants to have a basic knowledge of English and an ability to utilise the language orally.

\subsection{Instruments}

To answer the research question, a quasi-experimental study is conducted to determine whether CLT activities were effective for enhancing students' speaking skills. A quantitative data collection was conducted in the form of a pre-test before the intervention. It was applied to set a baseline for students' speaking ability and for comparison with the post-test results. Then, a post-test was assigned to the students to determine whether they benefited from the intervention and for comparison with the control group to reveal any enhancement.

\subsection{Data Collection Process}

\subsubsection{Ethics of the Research}

To ensure the authenticity of the current study, the researcher adhered to the following procedures:

First, the researcher made sure to notify the dean of the ELI of UJ about the study, and an approval form was received two days later. Second, students were notified that their participation in the study was voluntary and that they could withdraw from it any time they wanted. Third, students were informed that the grades of the pre-test 
and post-test would not influence their scores in the English language course. Fourth, students were requested to take the experiment seriously, and the tests were examined and assessed by the researcher and their main teacher to evaluate their performance on both tests. They were told that their answers on the tests would be recorded, and they agreed. Last, students' confidentiality was assured, and their information was used for the purposes of the study.

\subsubsection{The Pre-test}

The experiment took place over five weeks for an hour and a half per weekly speaking session, except for the pre- and post-tests, which were held during two sessions in the first and fifth weeks. First, an IELTS speaking pre-test was given to 21 students from both the experimental and control groups. Students were instructed about the nature of the IELTS speaking exam, the test sections, and the amount of time that would be spent on each section. The IELTS speaking exam consisted of three parts (see Appendix A); the first part was an interview with the examinee about themselves and their studies at university for two minutes. The second section centred on a real-life topic (e.g., getting along with a member of the family), about which students talked for five minutes. The third part was a further discussion about the previously mentioned topic for three minutes. Every student took 10 minutes to finish the exam. An analytic IELTS rubric was used to write down students' scores based on their performance, and their main teacher acted as a second assessor to limit the subjectivity of the evaluator. The researcher and the second assessor evaluated students' performance individually. Then, they agreed on a common score for every student. Students' answers were recorded just in case there was any kind of disagreement on the common score agreed on by the assessors.

\subsubsection{The Intervention}

The researcher taught the experimental group for an hour and a half per weekly speaking session for three weeks. The experimental group was taught using one of the following activities: problem-solving, interviewing, or role-playing. These activities involved group and pair work and were taken from Klippel's (1984) book entitled Keep Talking: Communicative Fluency Activities for Language Teaching. However, the control group was taught in the traditional way by their main teacher. To make the teaching sessions effective and intensive, the researcher wrote a lesson plan incorporating two activities for each speaking session. One of the activities was taken from Klippel's (1984) book, while the other was created based on students' weekly topic found in the pacing guides. The researcher provided the experimental group with constant feedback and scaffolding.

In the first speaking session, students were taught using an interview activity. The researcher based the teaching on an activity found in Klippel's (1984) book titled "Self-directed interview" for half an hour. The activity involves requesting students to practice creating questions about themselves and how to answer them. Then, they were asked to cooperate with their classmates to exchange the questions and practice them in the classroom. The second activity that was given to students was about the week's topic of taking a selfie; they were given an hour to complete the assignment. For this purpose, the researcher created a worksheet that required students to work in pairs to write questions and answers about applying for a photographer position. The purpose of this activity was to teach students the value of group work and how to prepare for job interviews.

In the second speaking session, students were immersed in a role-playing activity. The first activity asked students to work in four groups of five students to be applicants at a job interview, and an additional group was created to be employers hiring for a waitress position. The employer group were responsible for asking the questions and, based on the other groups' answers, the best one was chosen for the job. It took students half an hour to prepare and complete the activity. The second activity was about advertising. The students were given pictures of advertisements and situations; they were required to prepare for these situations in pair work and then role-play them in front of the class. The students created questions and answers based on the ad provided; then, each pair of students performed the role play in front of the class. The purpose of this activity was to improve students' self-confidence and help them overcome their shyness and anxiety about speaking in public.

In the third speaking session, the students were given a problem-solving activity. The first activity was a desert island problem. The researcher gave students a situation where they imagined themselves being abandoned on an isolated island. They were asked to work in pairs to write a list of 10 items they thought they needed to survive. After they wrote their lists of items, they were asked to share them and the reasons behind choosing them with the researcher. The second activity was based on the week's topic, which was vision 2030. Students were given a list of environmental and societal problems that Saudi citizens still find occurring in Saudi Arabia, and they were asked to work in pairs to find solutions for these problems. After they came up with solutions for them, they were asked to share the solutions with the rest of the class. 


\subsubsection{The Post-test}

In the fifth week, 21 students from both groups were given the same IELTS speaking test they took at the beginning of the experiment. The main teachers of the experimental and control groups helped the researcher as second assessors to make sure that the scores given were fair. Students' answers were recorded.

\subsection{Validity and Reliability of the IELTS Speaking Exam}

The validity of the IELTS speaking exam can be determined. For a test, validity means that the results are suitable, meaningful, and useful in assessing the required performance (Gronlund, 1998). The IELTS speaking exam is valid and authentic for the following reasons. The content validity of the test is assured since the IELTS exam is a direct testing method that assesses the test-takers' speaking ability (Brown \& Abeywickrama, 2010). Luoma (2004) noted that direct testing is considered valid since the test results reflect the level of the speaking skill that is being evaluated. Moreover, the IELTS test is considered to have face validity as the questions were revised by an English teacher who had been teaching in the TESOL field for many years (Creswell, 2012). Furthermore, the content and format of the test are guaranteed because the test was taken from the British Council website.

The reliability of the IELTS test is also assured. Test reliability means that the scores of the test are consistent and dependable (Brown \& Abeywickrama, 2010). The IELTS test is reliable since an analytic scale is used to give clear direction for scoring. Inter-rater reliability is confirmed; this type of reliability occurs when two assessors agree on a common score for each student, which increases the adherence to the scoring criteria and decreases the influence of evaluators' biased judgements (Brown \& Abeywickrama, 2010). Test-retest reliability is also assured; this type of reliability requires the researcher to use the same test twice at different time intervals, as was carried out in the present study (Creswell, 2012).

\section{Data Analysis Procedure and Results}

\subsection{Analysis and Results of Quantitative Data}

To answer the research question, descriptive analysis of the mean, median, and standard deviation are presented to show the difference between the pre- and post-test scores for the experimental and control groups. Then, an inferential statistical treatment of the Mann-Whitney $U$ test is conducted to illustrate the significant difference between the scores of the two groups.

Is there any difference between the experimental and control groups in the enhancement of their speaking skills at the ELI of UJ?

Table 1 presents the descriptive statistics for the experimental group scores for the pre-test and post-test.

Table 1. Descriptive statistics of experimental group scores for pre-test and post-test

\begin{tabular}{llll}
\hline Descriptive statistics for the experimental group & Mean & Median & Std. Deviation \\
\hline Pre-test & 3.48 & 3.00 & 1.030 \\
Post-test & 4.238 & 4.500 & 1.136 \\
\hline
\end{tabular}

Table 1 describes the difference in the median values between the pre-test and post-test scores for the experimental group. The median of the total scores for the pre-test is 3.00. Moreover, it can be seen that there is an increase in the median of the total scores in the post-test with a point average of 4.500 . As a result, there is a significant difference between the scores of the pre-test and post-test in the experimental group. Table 2 presents the descriptive statistics for the control group scores for the pre-test and post-test.

Table 2. Descriptive statistics of control group scores for pre-test and post-test

\begin{tabular}{llll}
\hline Descriptive statistics for the control group & Mean & Median & Std. Deviation \\
\hline Pre-test & 3.29 & 3.00 & 1.347 \\
Post-test & 3.714 & 3.00 & 1.401 \\
\hline
\end{tabular}

As shown in Table 2, the medians of the total scores of the pre-test and post-test are 3.00. After comparing the 
median scores of the two tests, there is no significant difference between the scores of the pre-test and post-test in the control group. Figure 1 compares the median values for the pre-test in the experimental and control groups.

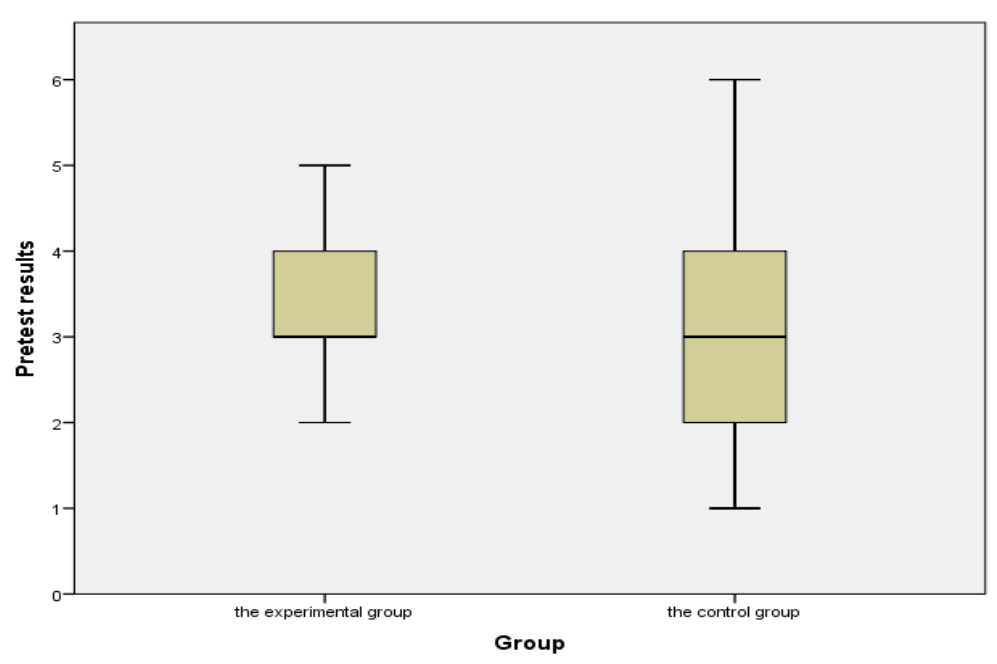

Figure 1. Comparison between the Pre-test scores of the experimental and control groups

Figure 1 compares the median values of the pre-test scores of the experimental and control groups. As can be seen, both groups revolve around the median rating (3.00), which indicates that the pre-test results of the two groups were equal.

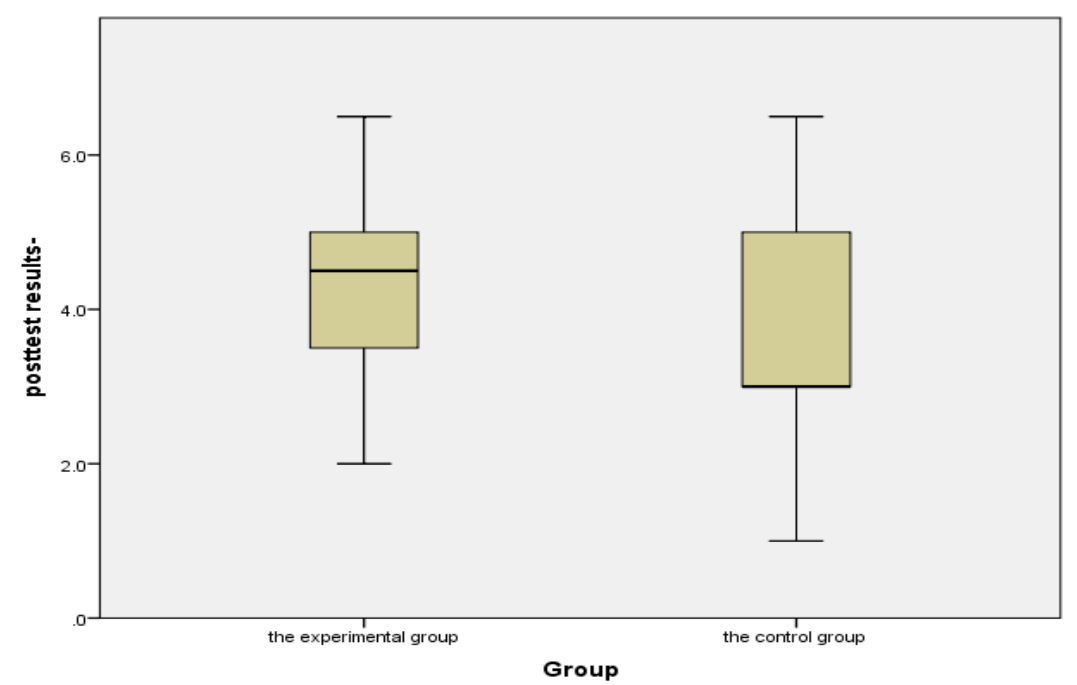

Figure 2. Comparison between the Post-test scores of the experimental and control groups

Figure 2 demonstrates the median values between the post-test scores of the experimental and control groups. As shown in Figure 2, the experimental group scored a higher rating $(\mathrm{Md}=4.500)$ compared to the control group $(\mathrm{Md}=3.00)$. Therefore, the experimental group scored higher on the post-test. To confirm these results, Table 3 shows the normality distribution of the scores of both groups to determine the inferential statistical treatment for the quantitative data. 
Table 3. Normality distribution test

\begin{tabular}{llllllll}
\hline Tests of Normality & \multicolumn{10}{l}{ Shapiro-Wilk } \\
& \multirow{2}{*}{ Group } & \multicolumn{2}{l}{ Kolmogorov-Smirnov ${ }^{\mathrm{a}}$} & \multicolumn{4}{l}{ Sig. } \\
& & Statistic & Df & Sig. & Statistic & df & Sig. \\
\hline Post-test/Pre-test & 1 & 0.25 & 21 & 0.001 & 0.878 & 21 & 0.014 \\
Difference & 2 & 0.304 & 21 & 0 & 0.762 & 21 & 0 \\
\hline
\end{tabular}

a. Lilliefors significance correction.

As shown in Table 3, the significant value for the pre-test and post-test scores is $(0.00)$ less than 0.05 (Sig. < 0.05). This indicates that the data is not normally distributed; therefore, the nonparametric Mann-Whitney U test is applied (Pallant, 2011). Moreover, the number of participants in the quasi-experimental study is less than 30, which supports the use of the Mann-Whitney U test.

The research question aims at finding the difference between the experimental and control groups in improving their speaking skills. Tables 4 and 5 and Figure 3 illustrate the Mann-Whitney $U$ test results.

Table 4. Mann-Whitney U Test

\begin{tabular}{lllll}
\hline Ranks & & & & \\
\hline & Group & N & Mean Rank & Sum of Ranks \\
\hline \multirow{3}{*}{ Post-test/Pre-test Difference } & 1 & 21 & 25.79 & 541.5 \\
& 2 & 21 & 17.21 & 361.5 \\
& Total & 42 & & \\
\hline
\end{tabular}

Table 5. Test Statistics for Mann-Whitney U Test

\begin{tabular}{ll}
\hline Test Statistics $^{\mathbf{a}}$ & \\
\hline & Post-test/Pre-test Difference \\
\hline Mann-Whitney U & 130.5 \\
Wilcoxon W & 361.5 \\
Z & $-2.364-$ \\
Asymp. Sig. (2-tailed) & 0.018 \\
\hline
\end{tabular}

a. Grouping variable: Group. 


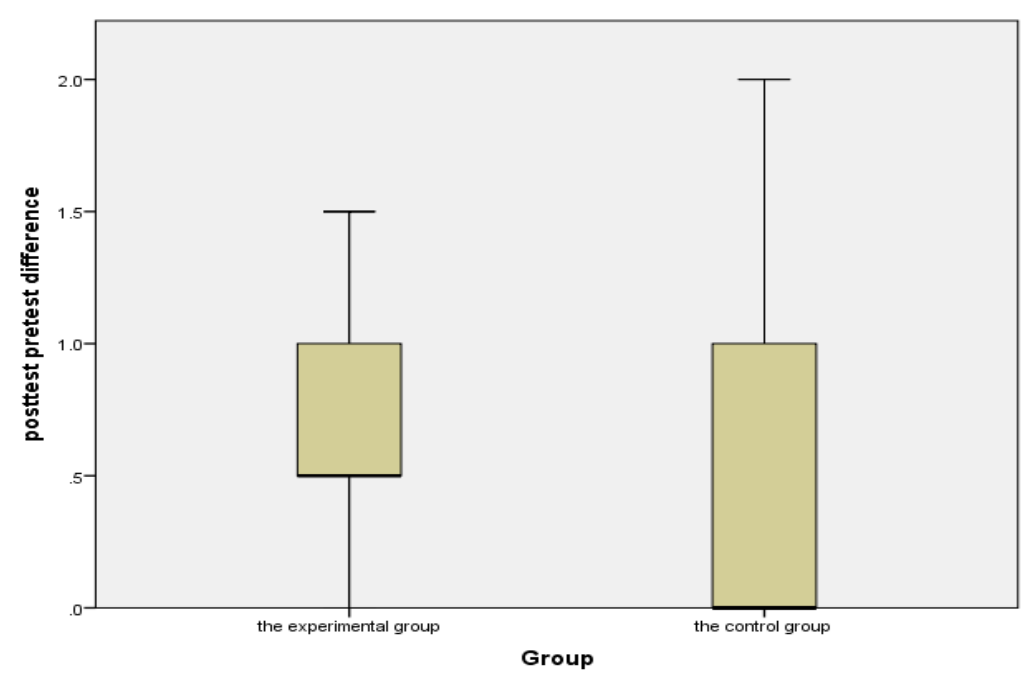

Figure 3. Comparing the difference between the Pre-and Post-test scores of the experimental and control groups

Table 6. Median scores for both groups

\begin{tabular}{lll}
\hline Report & & \\
\hline Post-test/Pre-test Difference & & \\
\hline Group & N & Median \\
Experimental Group & 21 & 0.5 \\
Control Group & 21 & 0 \\
Total & 42 & 0.5 \\
\hline
\end{tabular}

As seen in Tables 4 and 5 and Figure 3, the experimental group scored higher in point average $(M=25.79)$ than did the control group $(M=17.21)$. Moreover, the Mann-Whitney $U$ test revealed a significant difference between the experimental group $(\mathrm{Md}=0.500, \mathrm{n}=21)$ and the control group $(\mathrm{Md}=0.00, \mathrm{n}=21)$ (see Table 6 above), $\mathrm{U}=$ $130.500, \mathrm{Z}=-2.364$. In addition, the P-value is $(0.02)$, which is less than $(0.05)$, and the effect size is 0.03 which indicates a small effect. Therefore, the experimental group improved their speaking skills more than did the control group.

\section{Discussion}

The aim of the study was to examine the effect of using CLT activities on EFL students' speaking skills at the ELI of UJ. The findings in response to the research question showed that the experimental group scored higher than did the control group on the post-test; however, the effect size is small. The reason behind this small effect is that the intervention lasted for a short period of time (i.e., three speaking sessions). If the study lasted for at least four months and involved teaching students twice a week using CLT activities, better results might be obtained. As Ochoa et al. (2016) recommended in their study, if teachers use a CLT activity multiple times in the class, students will have more opportunities to practice English in the classroom. Another reason for the small effect size is that the number of participants was 21 from each group; if more participants were involved in the study, maybe there would be a larger difference between the groups' results.

Another reason to consider for the small effect size is the difficulty of promoting students' speaking skills in Saudi universities. As the literature shows, many researchers have concluded that students need more practice to better their performance (Al-Seghayer, 2011; Farooq, 2012). Other researchers have argued that CLT implementation in the classroom is challenging and complicated (Karavas-Doukas, 1996; Li, 1998; Hiep, 2007). The above-mentioned assertions are correct to some extent for many reasons. First, students are used to memorizing paragraphs and textbook exercises when they prepare for their tests, which hinders the improvement of their speaking ability (Alwazir \& Shukri, 2016). Second, Saudi students that have had bad experiences with learning the English language in high schools form negative views about the possibility of learning it at the university stage, and such views take a lot of time to overcome (Alwazir \& Shukri, 2016). Third, teaching the 
English language in the Arab context, and specifically in some Saudi universities, is still based on the traditional way of teaching, which can hinder students' learning (Al-Hazmi, 2006). Fourth, Saudi students use Arabic everywhere, which makes it hard for them to acquire the target language. This situation makes it hard for teachers to create opportunities for EFL students to practice English in the classroom (Khan, 2013). Last, Al Asmari (2015) noted that EFL students are still considered passive learners who lack motivation to participate in the classroom, have low proficiency levels in the English language, and resist taking part in communicative activities inside the classroom.

However, there is still a significant difference between the pre- and post-results of the experimental group. Some similar studies' findings were alighned with the present study's result in the usefulness of CLT for improving students' speaking ability ( $\mathrm{Wu}, 2010$; Algonhaim 2014). On that note, the purpose of CLT is to create opportunities for students to practice their speaking skills in real-life situations (Richards, 2006). The researcher followed this approach to create such genuine opportunities for EFL students at the University of Jeddah to improve their speaking ability. As has been confirmed by many studies, CLT is considered to be effective for improving students' speaking proficiency (Azadi et al., 2015; Wajid \& Saleem, 2017; Uzoma \& Ibrahim, 2018).

There are many positive sides to implementing CLT in EFL classrooms in Saudi universities. First, as Richards and Rogers (2001) argued, this teaching approach promotes learner-centredness, which results in a more communicative environment that offers students increased opportunities to practice speaking. Richards (2006) pointed out that creating genuine communication using CLT activities is the target of learning the English language. Indeed, the present researcher has seen an improvement in students' pronunciation, accent, vocabulary use, and fluency and accuracy through implementing communicative activities in the classroom.

EFL students at UJ tend to be shy about making mistakes in their oral production if they are asked to perform in front of their classmates, which results in the inability to speak publicly (Koran, 2015). For the experimental group, through CLT, opportunities were created for trial and error, listening to their classmates, and making mistakes and learning from them (Richards \& Rogers, 2001; Richards, 2006). Thus, they increased their self-confidence and overcame their shyness (Boonkit, 2010; Ochoa et al., 2016); they learned that their oral mistakes are an indication of improvement in their oral production (Richards, 2006). They also benefited a lot from pair and group work, which resulted in learning more information about their classmates.

As is well-known, English is a global language that must be learned by many, and speaking is one of the skills that requires a great deal of practice to acquire. By improving students' speaking ability, many opportunities will be created for them. Students will have opportunities to perform speaking activities in contexts such as ceremonies, job interviews, and activities for job training (Osborn et al., 2008). Moreover, speaking and communicative competence have become very important to acquire because they are part of new employment standards (Zaremba, 2006). Therefore, if students hope to find job opportunities in the future, they need to better their oral production and communication skills in English through taking part in CLT activities both inside and outside the classroom. That way, they can even improve their speaking ability and communication skills through listening to media and seeking more opportunities to speak English in real situations (Songsiri, 2007).

\section{Limitations of the Study}

The research presented in this paper has many limitations to consider. For example, the current study is limited to female students in the ELI of UJ, and the pre- and post-tests were limited to 21 students, which is not enough to obtain generalizable results. Moreover, the duration of the study is too short, which may affect students' performance; therefore, future studies might extend similar research over an entire semester to obtain more convincing results. In addition, the researcher did not teach the control group, which can be regarded as a limitation. However, it is much better that their main teacher taught them since the researcher would not have contributed anything new to the teaching of the class and wanted the students to stay on course by studying with their usual teacher.

\section{Pedagogical Implications and Recommendations for Further Research}

Many pedagogical implications need to be considered when it comes to implementing CLT activities in the classroom. Many Saudi universities still consider the traditional way of teaching and book-based teaching to be the most suitable methods when it comes to teaching EFL students during the preliminary year of any Saudi university. However, it is very important to consider other approaches to teaching in order to vary the teaching style in the classroom. Teachers are encouraged to try to implement CLT activities in the classroom to find out whether students prefer this type of teaching or not. They can conduct a needs analysis to discover what type of communicative activities students feel are relatable and comfortable to participate in. The administration of educational institutions is required to provide teachers with suitable materials to be able to implement CLT 
effectively in the classroom; they need to provide teachers with training sessions on how to conduct these activities efficiently. In addition, such training sessions will help teachers broaden their horizons sufficiently to consider the negative effect of relying entirely on a teacher-centred way of teaching and consider other approaches to enhance students' learning.

A qasi-experimental study could be conducted in the male section at the ELI of UJ through which more data related to CLT can be collected. Further investigation of implementing the CLT approach in various Saudi universities is needed. Therefore, a quasi-experimental study in both male and female sections will enrich the literature of this field. The current study focused on three types of communicative activities-interviewing, problem-solving, and role-playing - but the inclusion of more kinds of interactive activities when investigating the implementation of the CLT approach can lead to more relevant and coherent results. Finally, a future study could conduct observations of teachers teaching CLT activities in the classroom to obtain a more detailed understanding of CLT practices in different educational settings in Saudi Arabia.

\section{Acknowledgments}

First of all, I would like to thank Allah for helping and supporting me through this journey and for the patience he gave me to complete this research paper. Second, I would like to thank my parents and siblings for their encouragement and support throughout my master's journey. I would like to thank my sister and best friend, Amira AL-Garni, who has been through a lot and supported me through everything I decided to accomplish.

\section{References}

Al Asmari, A. A. (2015). Communicative Language Teaching in EFL university context: Challenges for teachers. Journal of Language Teaching and Research, 6(5), 976-984. https://doi.org/10.17507/jltr.0605.09

Alghonaim, A. (2014). Saudi university students' perceptions and attitudes towards Communicative and non-Communicative Activities and their relationship to Foreign Language anxiety. Research Journal of English Language and Literature, 2(2).

Alharbi, H. A. (2015). Improving students' English-Speaking Proficiency in Saudi Public Schools. International Journal of Instruction, 8(1), 105-116. https://doi.org/10.12973/iji.2015.818a

Al-Hazmi, S. (2006). Writing and reflections: Perspectives of Arab EFL learners. South Asian Language Review, $X V I(2), 36-52$.

Al-Jarf, R. (2008). The impact of English as an International Language (EIL) upon Arabic in Saudi Arabia. Asian EFL Journal, 10(4). 193-210.

Al-Seghayer, K. (2011). English teaching in Saudi Arabia: status, issues, and challenges. Hala Print Co.Riyadh, Saudi Arabia.

Alwazir, B., \& Shukri, N. (2016). The use of CLT in the Arab Context: A critical perspective. International Journal of English Language Education, 5(1), 15-32. https://doi.org/10.5296/ijele.v5i1.10486

Azadi, S., Aliakbari, M., \& Azizifar, A. (2015). The role of Classroom Interaction on improvement of Speaking among Iranian learners. International Journal of Language Learning and Applied Linguistics World (IJLLALW), 8(1), 126-135.

Banciu, V., \& Jireghie, A. (2012). Communicative Language teaching. Revista de Administratie Publica si Politici Sociale, 8, 95-98.

Boonkit, K. (2010). Enhancing the development of speaking skills for non-native speakers of English. Procedia-social and behavioral sciences, 2(2), 1305-1309. https://doi.org/10.1016/j.sbspro.2010.03.191

Brown, A. (1993). The role of test-takers' feedback in the test development process: Test-takers' reactions to a tape-mediated test of profi ciency in spoken Japanese. Language Testing, 10(3), 277-301. https://doi.org/10.1177/026553229301000305

Brown, H. D., \& Abeywickrama, P. (2010). Language assessment: Principles and classroom practices (2nd ed.). New York: Pearson Education.

Celce-Murica, M. (2001). Teaching English as a second language or foreign language (2nd ed.). New York: Newbury House.

Chaney, A. L., \& Burk, T. L. (1998). Teaching Oral Communication in grades K-8 (1st ed.). Boston, Allyn and Bacon: Pearson.

Cresswell, J. W. (2012). Educational research: Planning, conducting, and evaluating quantitative and 
qualitative research (4th ed.). New York, NY: Prentince Hall.

Derakhshan, A., Tahery, F., \& Mirarab, N. (2015). Helping adult and young learner to communicate in Speaking classes with confidence. Mediterranean Journal of Social Science, 6(2), 520-525. https://doi.org/10.5901/ mjss.2015.v6n2p520

Dörnyei, Z. (2007). Research methods in Applied Linguistics: quantitative, qualitative and mixed methodologies. Oxford: Oxford University Press.

Farooq, M. U. (2012). Effects of learner autonomy on teaching practices and outcomes in an ELT classroom. European Journal of Scientific Research, 94, 316-330.

Gonzalez, P. F., Ochoa, C. A., Cabrera, P. A., Castillo, L. M., Quinonez, A. L., Solano, L. M., \& Arias, M. O. (2015). EFL Teaching in the Amazon Region of Ecuador: A focus on Activities and resources for teaching Listening and Speaking skills. English Language Teaching, 8(8), 94-103. https://doi.org/10.5539/ elt.v8n8p94

Gronlund, N. E. (1998). Assessment of student achievement (6th ed.). Boston, MA: Allyn \& Bacon.

Hedge, T. (2001). Teaching and learning in the language classroom. Oxford, England: Oxford university press.

Hiep, P. H. (2007). Communicative language teaching: unity within diversity. ELT journal, 61(3), 193-201. https://doi.org/10.1093/elt/ccm026

Huff, C. (2012). Action research on using Role-play Activity in an adult ESL level-one class. Hamline University. Saint Paul, Minnesota.

Jamjoom, M. I. (2009). Female Islamic studies teachers in Saudi Arabia: A phenomenological study. Teaching and Teacher Education, 20, 1-12.

Karavas-Doukas, E. (1 996). Using attitude scales to investigate teachers' attitudes to the Communicative Approach. ELT Journal, 50(3), 187-196. https://doi.org/10.1093/elt/50.3.187

Kayi, Н. (2012). Teaching Speaking: Activities to promote Speaking in a second language. Новейшие научныле достижения, 12(2012).

Khan, I. (2013). Speaking skills and teaching strategies: The case of an EFL classroom. Elixir International Journal, 58(10), 14557-14560.

Klippel, F. (1984). Keep talking: Communicative Fluency Activities for language teaching. Cambridge university press.

Koran, S. (2015). The role of teachers in Developing learners' Speaking Skill. In B. Batur, \& I. Nişancı (Eds.), 6th the international visible conference on educational studies and applied linguistics: book of proceedings (pp. 400-416). Erbil- Kurdistan, Iraq: Ishik University.

Larsen-Freeman, D. (2000). Techniques and principles in Language teaching (2nd ed.). Oxford: Oxford University Press.

Li, D. (1998). It's always more difficult than you plan and imagine: Teachers' perceived difficulties in introducing the communicative approach in South Korea. TESOL Quarterly, 32(4), 677-703. https://doi.org/10.2307/3588000

Ochoa, C., Cabrera, P., Quiñónez, A., Castillo, L., \& González, P. (2016). The effect of Communicative Activities on EFL learners' motivation: A case of students in the amazon region of ecuador. Colombian Applied Linguistics Journal, 18(2), 39-48. https://doi.org/10.14483/calj.v18n2.10018

Oradee, T. (2012). Developing Speaking skills using three Communicative Activities (discussion, problem-solving, and role-playing). International Journal of Social Science and Humanity, 2(6), 533. https://doi.org/10.7763/IJSSH.2012.V2.164

Osborn, S., Osborn, M., \& Osborn, R. (2008). Public Speaking guidebook. Boston: Pearson.

Pallant, J. (2011). SPSS survival manual (4th ed.). Australia: national Library of Australia.

Patil, Z.N. (2008). Rethinking the objectives of teaching English in Asia. Asian EFL Journal, 10(4), 227-240.

Rababah, G., (2003). Communication problems facing Arab learners of English: A Personal Perspective. TEFL Web Journal, 2(1).

Richards, J. C., \&Rogers, T. (2001). Approaches and Methods in Language teaching. Cambridge, Cambridge University Press. https://doi.org/10.1017/CBO9780511667305 
Richards, J. C. (2006). Communicative Language Teaching today (1st ed.). New York, Cambridge university press.

Shumin, K. (2002). Factors to consider: Developing adult EFL students' Speaking abilities. In J. Richards, \& W. Renandya (Eds.), Methodology in language teaching: An anthology of current practice (pp. 204-211). United States of America, New York: Cambridge University Press. https://doi.org/10.1017/ CBO9780511667190.028

Siddiqui, O., \& Asif, F. (2018). Teachers' perceptions of the Communicative Language Approach at a Saudi University. International Journal of English Language Education, 6, 45-67. https://doi.org/10.5296/ijele.v6i1.12579

Songsiri, M. (2007). An action research study of promoting students' confidence in Speaking English. (Dissertation of Doctor of Education Degree, School of Arts, Education and Human Development, Victoria University, Australia).

Tompkins, P. K. (1998). Role-playing/Simulation. The Internet TESOL Journal, 4(8), 143-150.

Uzoma, N., \& Ibrahim, M. (2018). Effects of Communicative Language Teaching Approach on students' performance in Narrative Essay and Informal Letter Writing among senior secondary schools in Sokoto State, Nigeria. International Journal of Research and Innovation in Social Science, 2, 184-190.

Wajid, M. A., \& Saleem, M. (2017). Learner conformity to Communicative Language Teaching Approach in EFL contexts: A case study in Saudi Arabia. International Journal of Language and Linguistics, 4, 240-249.

Wu, K. H. (2010). The Relationship between Language Learners' Anxiety and Learning Strategy in the CLT Classrooms. International Education Studies, 3(1), 174-191. https://doi.org/10.5539/ies.v3n1p174

Zaremba, A. J. (2006). Speaking professionally. Canada: Thompson South-Western. https://doi.org/10.1117/ 2.1200601 .0082

Zhang, Y. (2009). Reading to Speak: Integrating Oral Communication Skills. English Teaching Forum, 47(1), $32-34$.

\section{Appendix A}

\section{The IELTS Speaking Test}

1- Introduction and Interview

What is your name?

How old are you?

What do you or are you planning to specialize in?

Why did you choose or are you planning to choose that subject?

Do you plan to get a job in the same field as your subject?

2- Individual Long Turn

Describe a member in your family you get on well with.

You should say:

- Who is it?

- What relationship you have to that person

- What that person is like

- What you do together

- Explain why you get on so well

3-Travel: Two-way discussion

We have talked about a a member in your family you get on well with. I'd like to discuss with you a few more questions related to this topic.

- Is family Important in your country?

- How do you think the family will change in the future? 
- Who do you think should be responsible for the care of the elderly, the family or the government?

\section{Copyrights}

Copyright for this article is retained by the author(s), with first publication rights granted to the journal.

This is an open-access article distributed under the terms and conditions of the Creative Commons Attribution license (http://creativecommons.org/licenses/by/4.0/). 